\title{
TTR
}

Traduction, terminologie, re?daction

\section{J. G. Quack-Stoilova. Bild und Translat. Amsterdam, Rodopi,} 1984.

\section{André Lefevere}

Volume 3, numéro 1, 1er semestre 1990

\section{L'agora de la traduction}

URI : https://id.erudit.org/iderudit/014738ar

DOI : https://doi.org/10.7202/014738ar

Aller au sommaire du numéro

\section{Éditeur(s)}

Association canadienne de traductologie

\section{ISSN}

0835-8443 (imprimé)

1708-2188 (numérique)

Découvrir la revue

\section{Citer cet article}

Lefevere, A. (1990). J. G. Quack-Stoilova. Bild und Translat. Amsterdam, Rodopi, 1984. TTR, 3(1), 129-131. https://doi.org/10.7202/014738ar d'utilisation que vous pouvez consulter en ligne.

https://apropos.erudit.org/fr/usagers/politique-dutilisation/ 
au rapport péritextuel/textuel dans son «modèle intégratif»; et, finalement, quoique l'auteur nous signale dès le début que l'ouvrage ne tient pas compte de la traduction automatique, l'Intelligence Artificielle me semble bien faire défaut dans la partie anthologique du livre: les développements en science cognitive et en informatique constituent un ensemble théorique essentiel à l'élaboration du travail théorique en traduction et en textologie.

L'ouvrage de Robert Larose paraît à un moment où la traductologie cherche à se définir comme discipline: la disette d'ouvrages pédagogiques capables de répandre les fondements théoriques de cette discipline illustre à quel point elle reste encore à construire. Développer des instruments efficaces qui permettent à l'étudiant d'en saisir les éléments conceptuels les plus importants est une tâche des plus pressantes. Les commentaires critiques qu'on vient de formuler ici ne devrait nullement obscurcir le fait que le livre de Robert Larose est une contribution fort importante à la réalisation de ce projet.

Donald Bruce University of Alberta

\section{J. G. Quack-Stoilova. Bild und Translat. Amsterdam, Rodopi, 1984.}

Dr. Quack-Stoilova's book smacks heavily of the doctoral dissertation, probably because in Holland doctoral dissertations still have to be published and disseminated, if only on a small scale, before the candidate can actually defend her dissertation. The «book», which appears to be a dissertation published as is, rather than a dissertation rewritten for publication, is cluttered with notes and bibliographic entries. A potentially interesting and lively subject has been dulled by the logical and even pedantic construction of the work as a whole.

The book is intended to be an inquiry into the problem of translating what the author calls «phraseologisms». This appears to be used both as an umbrella term for «image», «metaphor", and other concepts, and on its own, in the sense of "words usually encountered in a fixed sequence», such as «hand in hand», for instance.

Little effort is made to differentiate between the various uses of the term. In fact, «phraseology and other image-related occurrences in the text» are blithely likened to "raisins in the cake» (p. 3). Nothing against that: it is often better, in the long run, to cultivate a certain commonsensical fuzziness around the edges of such hard-to-define concepts as «image», and «metaphor». Yet the 
actual translation of the fuzzy items is detailed with extreme thoroughness.

Examples are taken from a work by Marx, from one by Engels, as well as from their most famous collaboration, The Communist Manifesto and their translations into Bulgarian. The author rightly points out that the Manifesto at least can claim a status equivalent to that of the Bible or the Quran in non-communist countries. She also briefly mentions the genealogy of the Bulgarian translations. It transpires that they were probably made following pre-existing Russian models, which might well invalidate some of the author's conclusions, if she drew any.

The reason why she does not is that she is content to illustrate conclusions arrived at by others, in the tradition of the old-style German doctoral dissertation. In this case, the author echos what members of the Leipzig school of translation studies: Kade, Jäger, Wotjak and Neubert, have to say about the translation of image-related language. She systematizes it and proceeds to apply it to the texts under consideration with hair-splitting perseverance.

The more is the pity because the Leipzig school is undeservedly little known in the West, as is the work of the Soviet translation scholar L. S. Barchudarov. Both the Leipzig scholars and Barchudarov have written many more interesting things than are mentioned here. In fact, translation studies as such might have been better served by a straightforward presentation of the ideas of either Barchudarov or the Leipzig school, not limited to their pronouncements on "phraseologisms" and without the obligatory comparisons between text and translations.

It should be pointed out in all fairness that the author is hampered somewhat by the target language she has chosen, Bulgarian, which happens to be her native language. Because Bulgarian is relatively little known ouside of Bulgaria, the author is faced with the plight of all of those who work with «minor" languages: she often has to retranslate the Bulgarian translations into German. This allows her to make her point, no doubt, but it also makes the book much longer than it need be and more difficult for the reader to follow.

The conceptual apparatus the author applies to the texts and their translations is built around such old standbys as adequacy and equivalence, subdivided into significative, metaphorical and stylistic ditto. The apparatus is then diversified into sub-sets of classifications applied to phraseologisms, the process of translation, metaphor, «realia», or culture-bound expressions, and "compensation", or ways of translating in such a way as to compensate later 
on in the translation for image-related occurrences that could not be translated.

The author shows time and again, with a zeal worthy of a worthier cause, that the translations do indeed fit the scheme she has set up. Circular reasoning is taken to extremes and the book fizzles out after a sufficient quota of examples has been analyzed.

The author has certainly given proof of her ability to work hard and to summarize clearly, logically and intelligibly. And that is precisely what those who sit in judgement over doctoral dissertation must be convinced of. Most readers, however, want some information out of a book, and need not be subjected to this type of demonstration.

It is a pity that so much time, energy and intelligence have been invested in this kind of study which merely "proves» what has already been proved over and over again. Obviously, the author herself is not to blame; instead, blame rests with the institution or institutions that award doctoral dissertations on the basis of this kind of work.

André Lefevere University of Texas at Austin

\section{Pamela Russell. How to Write a Précis. Ottawa, University of Ottawa Press, 1988, 76 p.}

At a time of steady advances in the field of translation studies and of an increasing awareness of the importance of translation pedagogy, it is surprising that there has not been more work done to produce effective teaching tools. This slim volume, while not specifically scholarly in nature, makes a refreshing addition to the meager body of translation textbooks. Drawing on her teaching experience at the University of Ottawa, the author makes judicious use of theoretical concepts in a straightforward and unpretentious manner and sets out a systematic method for teaching and acquiring skills of unquestionable practical value.

Précis-writing, a specialized type of summarizing, consists in reducing a text to one-third of the original length. It was developed essentially for two purposes: as a means of teaching language skills and as a means of testing people's linguistic and intellectual abilities. Some translation programs include préciswriting courses, and précis-writing as an exercise can be used in any writing course. The task of précis-writing involves a highly complex process of reading, understanding and rewriting and hence helps to develop analytical abilities as well as writing skills. 